\title{
Vlado Oštrić (9. rujna 1933. - 19. studenog 2017.)
}

Povjesničar prof. Vlado (Vlatko) Oštrić, istraživač suvremene hrvatske povijesti od sredine XIX. do sredine XX. stoljeća, rođen je u Šibeniku 9. rujna 1933., a umro u Zagrebu 19. studenog 2017. te je pokopan 23. studenog na groblju Mirogoj. Gimnaziju je završio u Zagrebu 1953. godine. Kao apsolvent na studiju povijesti u Zagrebu bio je od 1957. do 1963. nastavnik u osmogodišnjim školama u Velikom Trgovišću i Fužinama te je upravo u potonjem mjestu zavolio planine, šume i gore. $U$ to se vrijeme i oženio i postao otac sinu Zoranu. Obilasci naših najljepših planina, članstvo u planinarskim društvima, ali i vodstvo po prirodi postali su važan dio Oštrićeva života.

Vlado Oštrić zaposlio se 15. ožujka 1963. na mjestu stručnoga suradnika u Institutu za historiju radničkoga pokreta Hrvatske u Zagrebu, kojemu je tada na čelu dr. Franjo Tuđman. Bio je tajnik Sekcije za radnički pokret do 1918., u kojoj su članovi bili dr. Cvetka Knapić-Krhen, dr. Miroslava Despot, dr. Elza Tomac, Fedora Bikar i mr. Branka Pribić. Taj se odjel bavio istraživanjem Socijaldemokratske partije Hrvatske do Prvoga svjetskog rata, a nakon reforme koju je proveo direktor dr. Dušan Bilandžić, otpuštajući mnoge djelatnike u znanstvenom odjelu, Oštrić je na kraju ostao jedini član te sekcije. Kao i drugi suradnici, dobio je zadatak proučavanja literature o svojoj temi. Međutim, s obzirom na golemo mnoštvo napisa o socijaldemokraciji do 1914., Vlado Oštrić godinama je čitao časopise, novine, monografije i rukopise na različitim jezicima te je bio najbolji poznavalac povijesne literature do 1918. godine. Pritom je očito izgubio potrebnu crvenu nit i nikada nije objavio sintezu svoje teme, iako se među njegovih 250 članaka mogu naći vrijedni sadržaji, koji se mogu upoznati ponajprije na stranicama časopisa i zbornika radova. Najredovitije je surađivao u dvama institutskim časopisima, Putovima revolucije i Časopisu za suvremenu povijest. U prvom časopisu Instituta, Putovi revolucije, koji je izlazio od 1963. do 1967., Oštrić je objavio 18 naslova. Među tim člancima treba spomenuti referat „O nekim pitanjima proučavanja radničkog pokreta jugoslavenskih naroda do 1919. godine", koji je objavljen u br. 3-4/1964. Taj rad sadržava kritiku beogradskoga Pregleda istorije Saveza komunista Jugoslavije i potaknuo je lavinu napada na Institut i njegove suradnike. U kasnijim godinama kao da se smanjila Oštrićeva radna aktivnost; vjerojatno je na njega djelovalo rođenje mlađega sina Vedrana, koji je stradao prilikom poroda, pa je zahtijevao posebnu brigu i pažnju, koja je s godinama rasla. Mi smo to pratili, ali mislim da nismo dovoljno pomagali zaokupljeni teškoćama koje je Institut imao u pokušaju da opravda svoje postojanje i rad na području humanističkih i društvenih znanosti. Institut je bio stalno etiketiran kao Tuđmanov institut $\mathrm{i}$ njegov je rad bio pod višestrukom lupom tadašnjega režima, ali i druge strane - neomiljeno dijete među znanstvenim institucijama.

Od 1970. Vlado Oštrić objavljuje u novopokrenutom Časopisu za suvremenu povijest, u kojem je do 1990. objavio 45 radova raznih vrsta, ponajviše 
prikaza. Popis objavljenih članaka pokazuje da je pratio istraživanja na širem prostoru jugoistočne Europe; sve češće objavljuje osvrte na literaturu i skupove te šire historiografske osvrte (iz te skupine radova valja istaknuti osvrt na historiografiju o razdoblju od 1883. do 1918., napisan u suautorstvu s Mirjanom Gross i objavljen u Historijskom zborniku br. 31-32/1978.-79.). Čini se kao da je posustao u istraživanju socijaldemokracije, pa je njegova sinteza, odnosno ono do čega je došao istražujući socijaldemokraciju do 1918., objavljena 1982. i 1983. u Povijesnim prilozima, trećem institutskom časopisu, pod naslovom „Radnički pokret u jugoslavenskim zemljama od svojih početaka do 1918-1919. godine” (br. 1/1982., str. 11-61) te zaključno u članku „Socijalistički radnički pokret u Hrvatskoj do 1918. godine” (br. 2/1983., str. 9-62). Oštrić nije nikada doktorirao, za što je, smatram, kriv i njegov perfekcionizam. U njegovim radovima sve je trebalo biti savršeno i provjereno, što smo mi ostali iskorištavali pitajući ga za izvore i podatke koji se danas mogu lako naći na internetu, ali nekada su oni bili rezultat dugotrajnoga proučavanja literature i izvora.

Oštrić je bio član Uredničkoga odbora Časopisa za suvremenu povijest od br. 1/1982., a od br. 3/1988. do br. 3/1990. bio je i njegov glavni urednik. Kao urednik, otvorio je Časopis mnogim temama i obogatio dotadašnji sadržaj tiskajući pored dijela s raspravama i člancima u novootvorenim rubrikama i obilježavanja, obljetnice, diskusije, obavijesti, probleme metodologije povijesti, vijesti o znanstvenim skupovima i bibliografije. Uveo je rubrike $I z$ uredništva i In memoriam (prvi je bio posvećen tragično preminuloj Lydiji Sklevicky u br. 1-2/1990.). Kao urednik je na stranicama Časopisa objavio članak „Časopis za suvremenu povijest $u$ inozemnim sekundarnim i tercijarnim publikacijama” te analizu radova objavljenih u časopisu Naše teme od 1956. do 1966., čije je uredništvo bilo u zgradi Instituta i koji je - iako ga je financirala Partija - prvi počeo objavljivati različite teme iz suvremene povijesti koje su pisali sociolozi, politolozi, povjesničari, pravnici, ekonomisti i drugi stručnjaci.

Pored spomenutih, Oštrić je objavljivao i na stranicama časopisa Prilozi Instituta za istoriju radničkog pokreta (Sarajevo), Senjski zbornik, Naše teme, Jadranski zbornik, Dometi, Kaj, Povijest sporta, Nastava povijesti, Istorijski zapisi, Istarski mozaik, Problemi sjevernog Jadrana, Prilozi za istoriju socijalizma, Krčki zbornik i dr.

Veći broj znanstvenih rasprava Oštrić je objavio i u zbornicima sa znanstvenih skupova. Važan je njegov doprinos u monografiji Zagrebačka općina Trnje u radničkom i komunističkom pokretu i socijalističkoj revoluciji (Zagreb, 1981.); izradio je odličan prilog o urbanizaciji Trnja te dijelove o razdoblju socijalizma, kao i prilog za razdoblje do 1918. godine. Međutim, ta monografija imala je lošu sudbinu. Zbog istinitoga navoda da je Blaž Mesarić pod torturom izdao članove IV. rajonskoga partijskoga komiteta knjiga je, na njegov zahtjev i po nalogu dr. Vladimira Bakarića, bila povučena iz prodaje.

Od ostalih zbornika sa znanstvenih skupova u kojima je Oštrić objavio svoje priloge mogu biti spomenuti Materijali naučnog skupa „Prvo radničko 
društvo u jugoslavenskim zemljama - Osijek 1967." (Slavonski Brod, 1969.), Labinska republika 1921. godine (Rijeka, 1972.), Počeci socijalističke štampe na Balkanu (Beograd, 1974.), Radnički pokret Požeške kotline 1918-1941 (Slavonska Požega, 1978.), Radnički pokret Labinštine 1921-1941. sa širim osvrtom na Istru (Labin, 1981.), Historija i suvremenost: idejne kontroverze (Zagreb; Ljubljana, 1984.) i Povijest Rijeke (Rijeka, 1988.). Surađivao je i u Enciklopediji hrvatske povijesti $i$ kulture (Zagreb, 1980.) te Hrvatskom biografskom leksikonu (sv. 3, Zagreb, 1993.), a u Leksikonu novinarstva (Beograd, 1979.) obradio je povijest hrvatskoga novinstva objavivši šezdesetak natuknica. Umirovljen je 1998. godine.

Vlado Oštrić bio je aktivni planinar. Od 1984. član je Planinarskoga društva „Zagreb-Matica”, a od 1995. društva „Velebit”. U tim je društvima bio član uprave, bavio se markiranjem putova, a kraće vrijeme vodio je i izletnike u Gorski kotar, na Velebit i Julijske Alpe. U časopisima Hrvatski planinar i Naše planine objavio je više desetaka putopisa, osvrta i prikaza, a zastupljen je i u antologiji Hrvatska planinarska književnost (Zagreb, 1994.). Oštrićeva crtiCa „Goranova pjesma sa tihih putova” (Naše planine, Zagreb, 1966., str. 210) upoznaje nas s njegovom ljubavi za prirodu i da je bilo drugo vrijeme, Vlado Oštrić vjerojatno bi bio šumar i živio sretno u vezi s prirodom.

Moja suradnja s Vladom Oštrićem ostala mi je u najboljem sjećanju. Kada je nakon 1990. Institut dobio na korištenje čitavu zgradu u Opatičkoj 10 i kada ju je trebalo korjenito restaurirati, stradali su u prvom redu papiri i neprodana izdanja. Oštrić je tada složio brojne nepodijeljene separate iz časopisa Instituta te pozvao autore da ih uzmu jer za njih mogu imati određenu vrijednost. Takvih drugarskih gesta bilo je više i stoga mislim da Vladu Oštrića, koji je proveo 35 godina u Institutu i koji je rekao o socijaldemokraciji do 1918. ono što je trebalo reći, ne smijemo zaboraviti. Bio je dobar kolega, kvalitetan povjesničar i ideološki postojan. Zajedno smo radili u Institutu od 1964. do 1988. i mnoga sjećanja na moje kolege danas su mi življa nego prije. A današnjega Hrvatskog instituta za povijest ne bi bilo da ga nisu održali i podržali djelatnici koji su podnijeli sve napade i težinu rada u tzv. Tuđmanovu institutu, kada smo se branili kako smo znali - skromnošću, tolerancijom i radom, da danas Institut može slobodno djelovati kao važan faktor na polju hrvatske i europske historiografije.

Mira Kolar-Dimitrijević 